\title{
Application of Weighted Average Cost of Capital in European Market, Based on 2017 Great Portland Estate PIc (GPE)
}

\author{
Jiayun Liu \\ School of Business, Renmin University of China, Beijing 100872, China. \\ rbsliujiayun@163.com
}

\begin{abstract}
To explore the relationship between capital structures and cost of capital, related research and calculations have been done, based on the latest performance of Great Portland Estate plc (GPE) in 2017. Concept of Weighted Average Yield to Maturity is used to calculate the cost of debt by dividing all interest cost to total debt, while Capital Asset Price Model and Dividend Discount Model are used to calculate and then decide the cost of equity, and finally the Weighted Average Cost of Capital of this company will be figured out.
\end{abstract}

Keywords: Dividend discount model (DDM), Capital asset price model (CAPM), Capital structure of the company, the cost of debt, the cost of equity, Calculation of WACC.

\section{Introduction}

Great Portland Estate plc (GPE) is a property investment and development company operating in central London, which means that it is a good representation of European market. Current analysis about it is as followed, including calculation of the weighted average of capital cost and suggestions on how to raise capital for a new project.

Data used are mostly from the Internet. All analysis and relevant results are based on the data on 3rd Jan 2018, particularly based on its 2017 annual report (by 31st Mar, 2017).

\section{Data Sources and Modelling}

\subsection{Interest/Total Debt}

Theoretically, Credit Rating and Weighted Average YTM are two widely used methods to decide cost of debt. Because it is hard to find reliable credit rating of the debts of GPE, using Weighted Average YTM may be better. From this perspective, total interest payment, and market value of debts rather than book value, should be required. But in practice, some debts' market value cannot be estimated faithfully and the difference between their book value and market value is small, then book value can be taken as a good substitution.

\subsection{Dividend Discount Model (DDM)}

Considering the time value of cash flow, we can get a current price of benefits in the future by discounting. Assuming a dividend lasts forever and grows consistently at g, the stock price will turn into $P_{0}=\frac{D I V_{1}}{r_{e}-g}=\frac{D_{0}(1+g)}{r_{e}-g}$. Therefore, $r_{e}=\frac{D I V_{0}(1+g)}{P_{0}}+g=\frac{D I V_{1}}{P_{0}}+g=y+g$.

\subsection{Capital Asset Price Model (CAPM)}

The CAPM equation helps to estimate the required return of any stocks, once we have determined its beta, risk-free rate and market-risk premium or expected market return. I used UK 10-year gilt rate to determine risk-free rate, used FTSE 100 total return in last 5 years, to determine expected market portfolio return, and used GPE's total return in last 5 years together with FTSE 100 to determine beta. $r_{e}=r_{f}+\beta\left(r_{m}-r_{f}\right), \beta=\rho_{i, m} \cdot \sigma_{i} / \sigma_{m}=\operatorname{cov}(i, m) / \operatorname{var}(m)$. 
Table 1. (Great Portland Estates plc Annual Report 2017)

\begin{tabular}{cc} 
Debt & $f \mathrm{~m}$ \\
\hline Interest-bearing loans and borrowings: & \\
Debenture stock & 177.9 \\
Revolving credit facilities & 107.0 \\
Private placement notes & 164.4 \\
Convertible bonds & 159.4 \\
Obligation under finance leases & 35.9 \\
Pension liability & 5.8 \\
\hline TOTAL & 650.4 \\
Interest payment & $f \mathrm{~m}$ \\
\hline Interest on debenture stock & 8.0 \\
Interest on revolving credit facilities & 3.3 \\
Interest on private placement notes & 12.9 \\
Interest on convertible bonds & 1.5 \\
Interest on obligation under finance leases & 1.8 \\
\hline TOTAL & 27.5 \\
Cost of debt & $\%$ \\
\hline Interest payment/Debt & $4.2 \%$ \\
\hline
\end{tabular}

Table 2. The website Financial Times

\begin{tabular}{cc} 
DDM & $f$ \\
Current stock price & 6.85 \\
Dividend in the next period & 0.11 \\
Dividend growth (5 years) & $-10.35 \%$ \\
\hline The cost of equity & $-8.74 \%$ \\
\hline
\end{tabular}

Table 3. The website Financial Times \& Yahoo Finance

\begin{tabular}{ccccc|}
\multicolumn{5}{c}{ Monthly stock prices and return rates in last 5 years } \\
Date & GPE & GPE Return & $\begin{array}{c}\text { FTSE 100 } \\
\text { Price/GBX }\end{array}$ & $\begin{array}{c}\text { FTSE 100 Return } \\
\text { Rate }\end{array}$ \\
$2013-01-31$ & $\begin{array}{c}\text { Price/GBX } \\
\text { Rate }\end{array}$ & & $6,276.88$ & \\
$2013-02-28$ & 518.11 & $1.19 \%$ & $6,360.81$ & $1.34 \%$ \\
$2013-03-28$ & 522.00 & $0.73 \%$ & $6,411.74$ & $0.80 \%$ \\
$\ldots$ & $\ldots$ & $\ldots$ & $\ldots$ & $\ldots$ \\
$2017-11-30$ & 619.50 & $-0.32 \%$ & $7,326.67$ & $-2.22 \%$ \\
$2017-12-29$ & 688.50 & $11.14 \%$ & $7,687.77$ & $4.93 \%$ \\
\hline
\end{tabular}

Table 4. Calculations of Beta

\begin{tabular}{ccc} 
& $\mathrm{Rm}(\mathrm{FTSE} 100)$ & $\mathrm{Ri}$ (Great Portland Estate) \\
Average return (monthly) & $0.39 \%$ & $0.66 \%$ \\
Average return (yearly) & $4.68 \%$ & $7.92 \%$ \\
Std. $(\sigma)$ & 0.02917 & 0.05519 \\
Correlation Coefficient $\left(\rho_{\mathrm{i}, m}\right)$ & & 0.2975 \\
\hline Beta $\left(\beta_{1}\right)$ & & 0.5629
\end{tabular}

Above all, key components are determined as followed, leading to the cost of equity. $r_{f}=1.27 \%$, $\beta=0.5629, E\left(r_{m}\right) \approx$ average historical annual return rate of FTSE $100 \approx 4.68 \%$. So $r_{e}$ $=1.27 \%+0.5629 *(4.68 \%-1.27 \%)=3.19 \%$.

\subsection{Capital Structure of the Company}

While market value of debts and assets are difficult to get, I just used historical book value of debts and assets to estimate $\mathrm{D} / \mathrm{A}$ ratio and set a target ratio. 
Table 5. The website Financial Times

\begin{tabular}{cccccc} 
& FY2013 & FY2014 & FY2015 & FY2016 & FY2017 \\
Debts $(£ \mathrm{~m})$ & 705.6 & 652.6 & 667.0 & 650.7 & 573.6 \\
Total assets $(£ \mathrm{~m})$ & 2323 & 2644 & 3135 & 3701 & 3465 \\
D/A ratio & $30.37 \%$ & $24.68 \%$ & $21.28 \%$ & $17.58 \%$ & $16.55 \%$ \\
5-year D/A ratio & & & & & \\
\hline Target D/A ratio & & & & $30 \%$ \\
(assumption based on & & & & \\
historical data) & & & & \\
\hline
\end{tabular}

\section{Calculations of WACC and Critical Comments}

\subsection{The Cost of Debt}

I got $4.2 \%$ as cost of debt by calculating interest payment/debt. While according to debt analysis in Great Portland Estate annual report 2017, the weighted average cost of debt is $4.0 \%$, quite close to $4.2 \%$. As I have mentioned above, I used some debts' book value as a substitution of their market value, which may result in a lower "debt" and then a higher cost of debt than reality. So I chose $4.0 \%$ as cost of debt to apply WACC model.

\begin{tabular}{lrrr} 
Debt analysis & & & \\
\hline & Pro forma' & $\begin{array}{r}\text { March } \\
2017\end{array}$ & $\begin{array}{r}\text { March } \\
2016\end{array}$ \\
\hline Net debt excluding JVs (fm) & 309.9 & 502.8 & 568.0 \\
\hline Net gearing & $11.5 \%$ & $18.4 \%$ & $19.5 \%$ \\
\hline Total net debt including 50\% & 383.9 & 576.8 & 644.1 \\
\hline N non-recourse debt (fm) & $12.2 \%$ & $18.3 \%$ & $17.4 \%$ \\
\hline Loan to property value & $14.2 \%$ & $21.1 \%$ & $22.1 \%$ \\
\hline Total net gearing & $\mathrm{n} / \mathrm{a}$ & $\mathrm{n} / \mathrm{a}$ & $12.5 \mathrm{x}$ \\
\hline Interest cover & $2.7 \%$ & $3.0 \%$ & $3.7 \%$ \\
\hline Weighted average interest rate & $\mathrm{n} / \mathrm{a}$ & $4.0 \%$ & $3.9 \%$ \\
\hline Weighted average cost of debt & $100 \%$ & $82 \%$ & $100 \%$ \\
\hline \% of debt fixed/hedged & 618 & 378 & 472 \\
\hline Cash and undrawn facilities (fm) & & &
\end{tabular}

Fig 1. Great Portland Estates plc Annual Report 2017

\subsection{The Cost of Equity}

Using DDM, I got $-8.74 \%$ as cost of equity. This negative number is unrealistic, because equity financing usually costs something. There are reasons accounting for this result. Firstly, DDM assumes that the company pays dividend forever, which is unsure. More importantly, I used average dividend growth in last 5 years to estimate g. For one thing, historical growth rate is not equal to expected growth rate in the future. For another, dividend in 2017 falls suddenly compared to 2016, leading to a great decrease in average dividend growth in last 5 years. Therefore, I got $-10.35 \%$ as g, with kinds of errors. So, cost of equity driven by DDM cannot be used in WACC.

While though CAPM, I got 3.19\%. Considering that CAPM used far more data than DDM, cost of equity driven by CAPM is more reliable. But CAPM also makes errors, for that key components change over time. The shortcomings of CAPM are shown when I compared $3.19 \%$ to the cost of debt $4.0 \%$ above, I found it strange that cost of equity is lower than cost of debt, which is uncommon in practice. So, some adjustment must be done, with the help of articles and data.

To start with, besides calculating Beta by historical data, I found GPE's Beta 0.7858, directly according to FT. Given that I just picked up monthly data instead of daily data, the calculated Beta 0.5629 is not so accurate. Since other possible risk might be ignored when I did the calculations, the higher Beta should be more reliable. 


\section{Great Portland Estates PLC GPOR:LSE \\ Financials > General Financial \\ PRICE (GBX) TODAY'S CHANGE \\ SHARES TRADED 1YEAR CHANGE \\ 685.00 \\ $-3.00 /-0.44 \% 60.94 k$ \\ $4.71 \%$ \\ BETA \\ 0.7858}

Data delayed at least 15 minutes, as of Jan 052018 10:51 GMT.

Fig 2. The website Financial Times

Also, market risk premium is supposed to be the difference between expected equity market return and risk-free rate, $4.68 \%-1.27 \%=3.41 \%$. But a survey result in 2016 indicated, UK market risk premium is about $5.3 \%$, much higher than $3.42 \%$. Considering that FTSE 100 does not represent the whole equity market, real market may show a higher return rate, market risk premium can be more reliable after some adjustment. So, I added $2 \%$ to $3.41 \%$ to make up for potential return in the market. Then we got $5.41 \%$.

Figures 1 and 2 are graphic representations of the MRPs reported in table 2.

Table 2. Market Risk Premium (\%) used for 71 countries in 2016

\begin{tabular}{|l|l|r|r|r|r|r|r|r|r|}
\cline { 2 - 9 } \multicolumn{2}{l|}{} & Average & Median & St Dev & Max & min & Q1 & Q3 & $\mathbf{N}$ \\
\hline \multirow{2}{*}{1} & USA & $5,3 \%$ & $5,0 \%$ & $1,3 \%$ & $20,0 \%$ & $1,5 \%$ & $4,5 \%$ & $6,0 \%$ & 2536 \\
\cline { 2 - 10 } 2 & Spain & $6,2 \%$ & $6,0 \%$ & $1,4 \%$ & $12,0 \%$ & $1,5 \%$ & $5,0 \%$ & $6,8 \%$ & 817 \\
\hline 3 & Germany & $5,3 \%$ & $5,0 \%$ & $1,7 \%$ & $12,4 \%$ & $1,2 \%$ & $4,0 \%$ & $6,0 \%$ & 360 \\
\hline 4 & UK & $5,3 \%$ & $5,0 \%$ & $1,4 \%$ & $12,8 \%$ & $1,5 \%$ & $4,5 \%$ & $6,0 \%$ & 221 \\
\hline 5 & Italy & $5,6 \%$ & $5,5 \%$ & $1,5 \%$ & $10,1 \%$ & $2,0 \%$ & $4,8 \%$ & $6,0 \%$ & 152 \\
\hline
\end{tabular}

Fig 3. UK market risk

Key components are finally determined. $r_{f}=1.27 \%, \beta=0.7858$, market risk premium $\approx 5.41 \%$, so $r_{e}=1.27 \%+0.7858 * 5.41 \%=5.52 \%$. This adjusted number cannot be perfectly correct, but it is more realistic and also has data support. So, I used 5.52\% in WACC.

\subsection{Calculation of WACC}

This WACC is not right or wrong. It is in fact just a rough estimation based on an understanding of cost of debt, cost of equity and GPE's capital structure. Every coin has two sides. WACC can be very useful if its key components are scientifically determined, and very misleading if key components are not effective.

Table 6. WACC Calculations

\begin{tabular}{cc} 
WACC calculations & $4.0 \%$ \\
Cost of debt & $5.52 \%$ \\
Cost of equity & $30 \%$ \\
D/A ratio & $0 \%$ \\
\hline Corporate tax (REITs do not have Tc) & $5.06 \%$ \\
\hline WACC $=R_{d} \frac{D}{V}\left(1-T_{C}\right)+R_{e} \frac{E}{V}$ & \\
\hline
\end{tabular}

\section{Summary}

When the capital structure is optimized, the firm can make use of the effect of financial leverage, then cost of capital will be minimized and the firm's value will be maximized. To calculate capital cost, reasonable estimations of cost of debt and cost of equity are required. From this perspective, 
DDM, CAPM and many other models are good tools to get key intermediate figures. And then WACC model can be a powerful method to calculate cost of capital, estimate firms 'value and help with many important business decisions. Actually, besides WACC, many assumptions and theories about capital structure, like MM theory, trade-off theory, pecking order theory, and market timing theory, are also worth considering when making decisions.

Further research on the corresponding relationship between capital structures and cost of capital will provide more help to companies, either in corporate capital management or personal investment decisions.

\section{References}

[1]. Dial Wuhan. Comparison of the Cost of capital, the Cost of Debt and WACC [J]. Finance and Accounting Monthly, 2006(14).

[2]. Zhang Lidia. Research on Related Problems of Methods of Enterprise Value Evaluation [D]. Modern Enterprise Education, 2012(12).

[3]. Understanding and Application of the Discount Rate under Different Capital Structure [J]. Appraisal Journal of China, 2007(9). 